\title{
PENINGKATAN DISIPLIN KEHADIRAN MENGAJAR GURU DI KELAS MELALUI KETELADANAN KEPALA SEKOLAH DI SMP NEGERI 5 SENGKANG KABUPATEN WAJO
}

\author{
Hanatidah Altar \\ SMP Negeri 5 Sengkang Kabupaten Wajo \\ Email: hanatidahaltar@yahoo.co.id
}

\begin{abstract}
Abstrak:
Penelitian ini adalah Penelitian Tindakan Sekolah (School Action Research) yang bertujuan untuk mengetahui peningkatan disiplin guru dalam kehadiran mengajar di kelas melalui keteladanan Kepala Sekolah di SMP Negeri 5 Sengkang Kabupaten Wajo. Subjek penelitian ini adalah guru SMP Negeri 5 Sengkang sebanyak 13 orang. Penelitian ini dilaksanakan pada semester ganjil tahun pelajaran 2011/2012. Hasil penelitian menunjukkan bahwa Keteladanan Kepala Sekolah dapat meningkatkan Kedisiplinan guru dalam kehadiran mengajar di kelas, dimana pada pelaksanaan pembelajaran pra-siklus pada pertemuan pertama semua Guru hadir tepat waktu, karena merupakan hari pertama sekolah untuk tahun pelajaran 2011/2012. Pelaksanaan pembelajaran pada siklus I ada 10 orang Guru yang terlambat masuk mengajar di kelas, dan setelah pelaksanaan pembelajaran pada siklus II kedisiplinan guru dalam kehadiran mengajar di kelas mencapai $80 \%$ berdasarkan tanggapan responden (guru) mengenai keteladanan Kepala Sekolah, sedangkang berdasarkan hasil observasi 77 \% Guru yang masih terlambat kurang dari 5 menit, karena lokasi penelitian sulit terjangkau
\end{abstract}

\begin{abstract}
:
This research was school action research aiming at finding the increasing of the teachers' discipline in presence to teach in classroom through the principals' modeling at SMP Negeri 5 Sengkang, Wajo Regency. The subject of this research were the teachers of SMP Negeri 5 Sengkang consisting of 13 teachers. This research was conducted in 2011/2012 academic year. The result of the research showed that the principal's modeling can increase teacher's discipline in presence to teach in classroom proved by the data got through the classroom teaching process. In the first meeting of the pre cycle, all of the teachers came timely, because of the first day of school in 2011/2012 academic year. In cycle 1, there were 10 teachers who came late and in cycle 2, teachers' discipline in precence to teach in classroom got $80 \%$ which was got from teachers' responses about the principals' modeling. Based on the result of observation, there were $77 \%$ teachers coming 5 minutes late because the location of the research is difficult to be reached.
\end{abstract}

\section{Kata kunci:}

Disiplin, kehadiran mengajar, dan keteladanan

USAHA meningkatkan mutu pendidikan sesuai dengan cita-cita bangsa Indonesia, untuk mewujudkan kesejahteraan umum dan mencerdaskan kehidupan bangsa, di mana pendidikan mempunyai peranan penting dalam meningkatkan ketakwaan kepada Tuhan Yang Maha Esa, kecerdasan, dan ketrampilan. 
Untuk melaksanakan tugas dalam meningkatkan mutu pendidikan maka diadakan proses belajar mengajar, guru merupakan figur sentral, di tangan gurulah terletak kemungkinan berhasil atau tidaknya pencapaian tujuan belajar mengajar di sekolah. Oleh karena itu tugas dan peran guru bukan saja mendidik, mengajar dan melatih tetapi juga bagaimana guru dapat membaca situasi kelas dan kondisi siswanya dalam menerima pelajaran.

Untuk meningkatkan peranan guru dalam proses belajar mengajar dan hasil belajar siswa, maka guru diharapkan mampu menciptakan lingkungan belajar yang efektif dan akan mampu mengelola kelas. Guru adalah pendidik profesional dengan tugas utama mendidik dan mengevaluasi peserta didik, pada pendidikan anak usia dini jalur pendidikan formal, pendidikan dasar dan pendidikan menengah. Sementara pegawai, merupakan bagian dari tenaga kependidikan, yaitu anggota masyarakat yang mengabdikan diri dan diangkat untuk menunjang penyelenggaraan pendidikan. Dalam informasi tentang wawasan Wiyatamandala, kedisiplinan guru diartikan sebagai sikap mental yang mengandung kerelaan mematuhi semua ketentuan, peraturan dan norma yang berlaku dalam menunaikan tugas dan tangung jawab. ${ }^{1}$

Dari pengertian di atas dapat disimpulkan, kedisiplinan guru dan pegawai adalah sikap penuh kerelaan dalam mematuhi semua aturan dan norma yang ada dalam menjalankan tugasnya sebagai bentuk tanggung jawabnya terhadap pendidikan anak didiknya. Karena bagaimana pun seorang guru atau tenaga kependidikan (pegawai), merupakan cermin bagi anak didiknya dalam sikap atau teladan, dan sikap disiplin guru dan tenaga kependidikan (pegawai) akan memberikan warna terhadap hasil pendidikan yang jauh lebih baik.

Keberhasilan proses pembelajaran sangat bergantung pada beberapa faktor diantaranya adalah faktor guru. Guru sangat memegang peranan penting dalam keberhasilan proses pembelajaran. Guru yang mempunyai kompetensi yang baik tentunya akan sangat mendukung keberhasilan proses pembelajaran.

Peranan guru selain sebagai seorang pengajar, guru juga berperan sebagai seorang pendidik. Pendidik adalah setiap orang yang dengan sengaja mempengaruhi orang lain untuk mencapai tingkat kemanusiaan yang lebih tinggi. ${ }^{2}$ Sehinggga sebagai pendidik, seorang guru harus memiliki kesadaran atau merasa mempunyai tugas dan kewajiban untuk mendidik. Tugas mendidik adalah tugas yang amat mulia atas dasar "panggilan" yang teramat suci. Sebagai komponen sentral dalam sistem pendidikan, pendidik mempunyai peran utama dalam membangun fondamenfondamen hari depan corak kemanusiaan. Corak kemanusiaan yang dibangun dalam rangka pembangunan nasional kita adalah "manusia Indonesia seutuhnya", yaitu manusia yang beriman dan bertakwa kepada Tuhan Yang Maha Esa, percaya diri, disiplin, bermoral dan bertanggung jawab. Untuk mewujudkan hal itu, keteladanan dari seorang guru sebagai pendidik sangat dibutuhkan. ${ }^{3}$

Keteladanan Kepala Sekolah dapat dilihat dari prilaku guru sehari-hari baik di dalam sekolah maupun di luar sekolah. Selain keteladanan guru, kedisiplinan guru 
juga menjadi salah satu hal penting yang harus dimiliki oleh guru sebagai seorang pengajar dan pendidik.

Fakta di lapangan yang sering kita jumpai di sekolah adalah kurang disiplinnya guru, terutama kedisiplinan dalam kegiatan pembelajaran di kelas. Seringkali ditemukan kelas kosong tanpa guru pengganti apabila gurunya tidak hadir mengisi jadwalnya. Kasus ini hanya satu dari sekian kasus yang terlaporkan. Persoalannya, masalah-masalah tersebut sepertinya tanpa penyelesaian, berulang dan telah berlangsung lama. Pada tataran ini, kepala sekolah berperan menata kelas termasuk memerankan fungsinya sebagai supervisor pembelajaran.

Keadaan tersebut tidak berbeda jauh dari keadaan pada lokus penelitian ini. Dalam studi awal menunjukkan beberapa kelemahan terkait pelaksanaan fungsi kepala sekolah di dalam meningkatkan kedisiplinan guru sehingga mereka dapat mengoptimalkan kinerja profesionalnya. Kinerja profesional guru salah satunya mungkin ditingkatkan melalui keteladanan kepala sekolah.

Berdasarkan uraian di atas, penulis tertarik untuk melakukan penelitian tindakan sekolah dengan judul: "Upaya Meningkatkan Disiplin Guru dalam Kehadiran Mengajar di kelas Melalui Keteladanan Kepala Sekolah di SMP Negeri 5 Sengkang Kabupaten Wajo". Rumusan masalah dalam penelitian ini adalah: "Apakah keteladanan kepala sekolah dapat meningkatkan kedisiplinan guru dalam kehadiran mengajar di kelas?"

\section{TINJAUAN TEORETIS}

Di masa lalu, kepala sekolah yang berperan sebagai manajer yang efektif telah dianggap cukup. Di masa itu, kebanyakan kepala sekolah diharapkan mentaati ketentuan dan kebijakan Dinas Pendidikan, mengatasi isu-isu ketenagaan, pengadaan fasilitas dan infrastruktur, menyesuaikan anggaran, memelihara agar gedung sekolah nyaman dan aman, memelihara hubungan dengan masyarakat, memastikan kantin sekolah dan UKS berjalan lancar. Semua ini masih tetap harus dilakukan oleh kepala sekolah. Akan tetapi, sekarang kepala sekolah harus melakukan hal yang lebih dari semua itu.

Berbagai penelitian menunjukkan peran kunci yang dapat dilakukan oleh kepala sekolah adalah untuk meningkatkan belajar dan pembelajaran atau sebagai leaders for learning (The Institute for Educational Leadership). Para kepala sekolah harus mengetahui isi pelajaran dan teknik-teknik pedagogis. Para kepala sekolah harus bekerja bersama guru untuk meningkatkan keterampilan. Kepala sekolah harus mengumpulkan, menganalisis, dan menggunakan data dengan cara-cara yang menumbuhkan keunggulan. Mereka harus berkumpul bersama siswa, guru, orang tua, organisasi-organisasi layanan sosial dan kesehatan, Organisasi kepemudaan, dunia usaha, warga sekitar sekolah untuk meningkatkan kinerja siswa. Selanjutnya para kepala sekolah itu juga harus memiliki keterampilan dan pengetahuan kepemimpinan dalam rangka memanfaatkan kewenangannya untuk mencari strategistrategi yang diperlukan. ${ }^{4}$ 
Mereka seharusnya melakukan itu semua, akan tetapi sayang, sering dijumpai bahwa mereka tidak melakukannya. Meskipun masyarakat pada umumnya memberi sorotan kepada kepala sekolah ketika hasil Ujian Nasional siswa diumumkan dan mengajukan usul untuk memberi sanksi apabila sekolah tidak menunjukkan hasil sebagaimana diharapkan, para kepala sekolah di masa lalu tidak banyak melalukan persiapan atau melakukan pengembangan keprofesionalan berkelanjutan untuk membekali diri dalam rangka melaksanakan peran baru tersebut. Pihak pemerintah daerah, atau dinas pendidikan, selama ini juga lebih banyak mendorong kepala sekolah untuk sekedar mentaati peraturan yang ada, berusaha untuk mengelola tuntutan kepala sekolah yang berlipat ganda di era meningkatnya harapan, kebutuhan siswa yang kompleks, akuntabilitas yang terus meningkat, peningkatan keberagaman, dan sabagainya.

Tidak ada alternatif lain, masyarakat di seluruh negeri ini harus "reinvent the principalship" untuk memampukan para kepala sekolah dalam menghadapi tantangan abad 21, dan untuk menjamin para pemimpin bagi belajar siswa yang dibutuhkan untuk membimbing agar sekolah dan siswa yang dipimpinnya mencapai keberhasilan.

Keberhasilan siswa dalam pembelajaran serta peningkatan mutu sekolah tidak hanya menjadi tanggung jawab kepala sekolah saja, akan tetapi menjadi tanggung jawab bersama antara, guru, orang tua atau masyarakat serta pemerintah.

Dalam bidang pendidikan, yang dimaksud dengan mutu memiliki pengertian sesuai dengan makna yang terkandung dalam siklus pembelajaran. Secara ringkas dapat disebutkan beberapa kata kunci pengertian mutu, yaitu: sesuai standar (fitness to standard), sesuai penggunaan pasar/pelanggan (fitness to use), sesuai perkembangan kebutuhan (fitness to latent requirements), dan sesuai lingkungan global (fitness to global environmental requirements). ${ }^{5}$ Adapun yang dimaksud mutu sesuai dengan standar, yaitu jika salah satu aspek dalam pengelolaan pendidikan itu sesuai dengan standar yang telah ditetapkan. Garvin seperti dikutip Gaspersz mendefinisikan delapan dimensi yang dapat digunakan untuk menganalisis karakteristik suatu mutu, yaitu: (1) kinerja (performance), (2) feature, (3) kehandalan (reliability), (4) konfirmasi (conformance), (5) durability, (6) kompetensi pelayanan (servitability), (7) estetika (aestetics), dan (8) kualitas yang dipersepsikan pelanggan yang bersifat subjektif. ${ }^{6}$ Dalam pandangan masyarakat umum sering dijumpai bahwa mutu sekolah atau keunggulan sekolah dapat dilihat dari ukuran fisik sekolah, seperti gedung dan jumlah ekstrakurikuler yang disediakan. Ada pula masyarakat yang berpendapat bahwa kualitas sekolah dapat dilihat dari jumlah lulusan sekolah tersebut yang diterima di jenjang pendidikan selanjutnya. Untuk dapat memahami kualitas pendidikan formal di sekolah, perlu kiranya melihat pendidikan formal di sekolah sebagai suatu sistem. Selanjutnya mutu sistem tergantung pada mutu komponen yang membentuk sistem, serta proses yang berlangsung hingga membuahkan hasil.

Kinerja guru menjadi salah satu unsur dalam upaya peningkatan mutu sekolah. Kinerja guru meliputi kedisiplinan guru dan etos kerja. Apabila kedisiplinan telah 
menjadi budaya sekolah, maka arah pencapaian peningkatan mutu sekolah akan tercapai.

Kedisiplinan berasal dari kata disiplin, yang berarti ketaatan terhadap aturan dan norma yang berlaku dalam kehidupan bermasyarakat, berbangsa dan bernegara yang dilaksanakan secara sadar dan iklhlas, baik lahir maupun batin.

Adapun implementasi dari sikap disiplin itu dapat diterapkan melalui tiga budaya, yaitu:

1. Budaya tertib, yaitu: membiasakan diri untuk hidup tertib, seperti tertib: waktu, mengajar, administrasi, pakaian, keuangan, dan lain-lain.

2. Budaya bersih, yaitu: membiasakan diri hidup bersih, seperti: bersih diri, pakaian dan bersih lingkungan.

3. Budaya kerja, yaitu: membiasakan diri untuk bekerja dengan sungguh-sungguh sesuai dengan peraturan yang berlaku, baik peraturan di tempat kerja maupun peraturan yang dibuat bersama sebagai pedoman untuk menjalankan aktifitas sehari-hari di sekolah.7

Adapun bentuk Implementasi dari Kedisiplinan Guru adalah:

1. Hadir di sekolah 15 (lima belas menit) sebelum pelaksanaan pembelajaran dimulai.

2. Menandatangani daftar hadir setiap hari secara rutin.

3. Mengatur siswa yang akan masuk ke kelas dengan berbaris secara teratur.

4. Hadir dan meninggalkan sekolah tepat waktu.

5. Melaksanakan semua tugas secara tertib, teratur, dan rutin.

6. Membuat Program Semester.

7. Membuat persiapan mengajar (RPP), jurnal mengajar setiap hari.

8. Memeriksa setiap pekerjaan atau latihan siswa.

9. Menyelesaikan administrasi kelas secara baik dan teratur.

10. Tidak meninggalkan sekolah tanpa izin.

11. Tidak merokok selama berada di lingkungan sekolah.

12. Mengisi buku agenda Guru.

13. Mengawasi siswa selama jam istirahat.

14. Mencatat kehadiran siswa setiap hari.

15. Melaksanakan 7 K. 8

Budaya sekolah adalah nilai-nilai dominan yang didukung oleh sekolah atau falsafah yang menuntun kebijakan sekolah terhadap semua unsur dan komponen sekolah termasuk stakeholders pendidikan, seperti cara melaksanakan pekerjaan di sekolah serta asumsi atau kepercayaan dasar yang dianut oleh personil sekolah. Budaya sekolah merujuk pada suatu system nilai, kepercayaan dan norma-norma yang diterima secara bersama, serta dilaksanakan dengan penuh kesadaran sebagai perilaku alami, yang dibentuk oleh lingkungan yang menciptakan pemahaman yang sama diantara seluruh unsur dan personil sekolah baik itu kepala sekolah, guru, staf, siswa dan jika perlu membentuk opini masyarakat yang sama dengan sekolah. ${ }^{9}$ 
Beberapa manfaat yang bisa diambil dari upaya pengembangan budaya sekolah, diantaranya: (1) menjamin kualitas kerja yang lebih baik; (2) membuka seluruh jaringan komunikasi dari segala jenis dan level baik komunikasi vertical maupun horisontal; (3) lebih terbuka dan transparan; (4) menciptakan kebersamaan dan rasa saling memiliki yang tinggi; (4) meningkatkan solidaritas dan rasa kekeluargaan; (5) jika menemukan kesalahan akan segera dapat diperbaiki; dan (6) dapat beradaptasi dengan baik terhadap perkembangan IPTEK. Selain beberapa manfaat di atas, manfaat lain bagi individu (pribadi) dan kelompok adalah: (1) meningkatkan kepuasankerja; (2) pergaulan lebih akrab; (3) disiplin meningkat; (4) pengawasan fungsional bias lebih ringan; (5) muncul keinginan untuk selalu ingin berbuat proaktif; (6) belajar dan berprestasi terus serta; dan (7) selalu ingin memberikan yang terbaik bagi sekolah, keluarga, orang lain dan diri sendiri.10

Upaya pengembangan budaya sekolah seyogyanya mengacu kepada beberapa prinsip berikut ini:

1. Berfokus pada Visi, Misi dan Tujuan Sekolah. Pengembangan budaya sekolah harus senantiasa sejalan dengan visi, misi dan tujuan sekolah. Fungsi visi, misi, dan tujuan sekolah adalah mengarahkan pengembangan budaya sekolah. Visi tentang keunggulan mutu misalnya, harus disertai dengan program-program yang nyata mengenai penciptaan budaya sekolah.

2. Penciptaan Komunikasi Formal dan Informal. Komunikasi merupakan dasar bagi koordinasi dalam sekolah, termasuk dalam menyampaikan pesan-pesan pentingnya budaya sekolah. Komunikasi informal sama pentingnya dengan komunikasi formal. Dengan demikian kedua jalur komunikasi tersebut perlu digunakan dalam menyampaikan pesan secara efektif dan efisien.

3. Inovatif dan Bersedia Mengambil Resiko. Salah satu dimensi budaya organisasi adalah inovasi dan kesediaan mengambil resiko. Setiap perubahan budaya sekolah menyebabkan adanya resiko yang harus diterima khususnya bagi para pembaharu. Ketakutan akan resiko menyebabkan kurang beraninya seorang pemimpin mengambil sikap dan keputusan dalam waktu cepat.

4. Memiliki Strategi yang Jelas. Pengembangan budaya sekolah perlu ditopang oleh strategi dan program. Startegi mencakup cara-cara yang ditempuh sedangkan program menyangkut kegiatan operasional yang perlu dilakukan. Strategi dan program merudpakan dua hal yang selalu berkaitan.

5. Berorientasi Kinerja. Pengembangan budaya sekolah perlu diarahkan pada sasaran yang sedapat mungkin dapat diukur. Sasaran yang dapat diukur akan mempermudah pengukuran capaian kinerja dari suatu sekolah.

6. Sistem Evaluasi yang Jelas. Untuk mengetahui kinerja pengembangan budaya sekolah perlu dilakukan evaluasi secara rutin dan bertahap: jangka pendek, sedang, dan jangka panjang. Karena itu perlu dikembangkan sistem evaluasi terutama dalam hal: kapan evaluasi dilakukan, siapa yang melakukan dan mekanisme tindak lanjut yang harus dilakukan.

7. Memiliki Komitmen yang Kuat. Komitmen dari pimpinan dan warga sekolah 
sangat menentukan implementasi program-program pengembangan budaya sekolah. Banyak bukti menunjukkan bahwa komitmen yang lemah terutama dari pimpinan menyebabkan program-program tidak terlaksana dengan baik.

8. Keputusan Berdasarkan Konsensus. Ciri budaya organisasi yang positif adalah pengembilan keputusan partisipatif yang berujung pada pengambilan keputusan secara konsensus. Meskipun hal itu tergantung pada situasi keputusan, namun pada umumnya konsensus dapat meningkatkan komitmen anggota organisasi dalam melaksanakan keputusan tersebut.

9. Sistem Imbalan yang Jelas. Pengembangan budaya sekolah hendaknya disertai dengan sistem imbalan meskipun tidak selalu dalam bentuk barang atau uang. Bentuk lainnya adalah penghargaan atau kredit poin terutama bagi siswa yang menunjukkan perilaku positif yang sejalan dengan pengembangan budaya sekolah.

10. Evaluasi Diri. Evaluasi diri merupakan salah satu alat untuk mengetahui masalah-masalah yang dihadapi di sekolah. Evaluasi dapat dilakukan dengan menggunakan pendekatan curah pendapat atau menggunakan skala penilaian diri. Kepala sekolah dapat mengembangkan metode penilaian diri yang berguna bagi pengembangan budaya sekolah. ${ }^{11}$

Selain mengacu kepada sejumlah prinsip di atas, upaya pengembangan budaya sekolah juga seyogyanya berpegang pada asas-asas berikut ini:

1. Kerjasama tim. Pada dasarnya sebuah komunitas sekolah merupakan sebuah tim/kumpulan individu yang bekerja sama untuk mencapai tujuan. Untuk itu, nilai kerja sama merupakan suatu keharusan dan kerjasama merupakan aktivitas yang bertujuan untuk membangun kekuatan-kekuatan atau sumber daya yang dimilki oleh personil sekolah.

2. Kemampuan. Menunjuk pada kemampuan untuk mengerjakan tugas dan tanggung jawab pada tingkat kelas atau sekolah. Dalam lingkungan pembelajaran, kemampuan profesional guru bukan hanya ditunjukkan dalam bidang akademik tetapi juga dalam bersikap dan bertindak yang mencerminkan pribadi pendidik.

3. Keinginan. Keinginan di sini merujuk pada kemauan atau kerelaan untuk melakukan tugas dan tanggung jawab untuk memberikan kepuasan terhadap siswa dan masyarakat. Semua nilai di atas tidak berarti apa-apa jika tidak diiringi dengan keinginan. Keinginan juga harus diarahkan pada usaha untuk memperbaiki dan meningkatkan kemampuan dan kompetensi diri dalam melaksanakan tugas dan tanggung jawab sebagai budaya yang muncul dalam diri pribadi baik sebagai kepala sekolah, guru, dan staf dalam memberikan pelayanan kepada siswa dan masyarakat.

4. Kegembiraan (happiness). Nilai kegembiraan ini harus dimiliki oleh seluruh personil sekolah dengan harapan kegembiraan yang kita miliki akan berimplikasi pada lingkungan dan iklim sekolah yang ramah dan menumbuhkan perasaan puas, nyaman, bahagia dan bangga sebagai bagian dari personil sekolah. Jika perlu dibuat wilayah-wilayah yang dapat membuat suasana dan memberi nuansa 
yang indah, nyaman, asri dan menyenangkan, seperti taman sekolah ditata dengan baik dan dibuat wilayah bebas masalah atau wilayah harus senyum dan sebagainya.

5. Hormat (respect). Rasa hormat merupakan nilai yang memperlihatkan penghargaan kepada siapa saja baik dalam lingkungan sekolah maupun dengan stakeholders pendidikan lainnya. Keluhan-keluhan yang terjadi karena perasaan tidak dihargai atau tidak diperlakukan dengan wajar akan menjadikan sekolah kurang dipercaya. Sikap respek dapat diungkapkan dengan cara memberi senyuman dan sapaan kepada siapa saja yang kita temui, bisa juga dengan memberikan hadiah yang menarik sebagai ungkapan rasa hormat dan penghargaan kita atas hasil kerja yang dilakukan dengan baik. Atau mengundang secara khusus dan menyampaikan selamat atas prestasi yang diperoleh dan sebagaianya.

6. Jujur (honesty). Nilai kejujuran merupakan nilai yang paling mendasar dalam lingkungan sekolah, baik kejujuran pada diri sendiri maupun kejujuran kepada orang lain. Nilai kejujuran tidak terbatas pada kebenaran dalam melakukan pekerjaan atau tugas tetapi mencakup cara terbaik dalam membentuk pribadi yang obyektif. Tanpa kejujuran, kepercayaan tidak akan diperoleh. Oleh karena itu budaya jujur dalam setiap situasi dimanapun kita berada harus senantiasa dipertahankan. Jujur dalam memberikan penilaian, jujur dalam mengelola keuangan, jujur dalam penggunaan waktu serta konsisten pada tugas dan tanggung jawab merupakan pribadi yang kuat dalam menciptakan budaya sekolah yang baik.

7. Disiplin (discipline). Disiplin merupakan suatu bentuk ketaatan pada peraturan dan sanksi yang berlaku dalam lingkungan sekolah. Disiplin yang dimaksudkan dalam asas ini adalah sikap dan perilaku disiplin yang muncul karena kesadaran dan kerelaan kita untuk hidup teratur dan rapi serta mampu menempatkan sesuatu sesuai pada kondisi yang seharusnya. Jadi disiplin disini bukanlah sesuatu yang harus dan tidak harus dilakukan karena peraturan yang menuntut kita untuk taat pada aturan yang ada. Aturan atau tata tertib yang dipajang dimana-mana bahkan merupakan atribut, tidak akan menjamin untuk dipatuhi apabila tidak didukung dengan suasana atau iklim lingkungan sekolah yang disiplin. Disiplin tidak hanya berlaku pada orang tertentu saja di sekolah tetapi untuk semua personil sekolah tidak kecuali kepala sekolah, guru dan staf.

8. Empati (empathy). Empati adalah kemampuan menempatkan diri atau dapat merasakan apa yang dirasakan oleh orang lain namun tidak ikut larut dalam perasaan itu. Sikap ini perlu dimiliki oleh seluruh personil sekolah agar dalam berinteraksi dengan siapa saja dan dimana saja mereka dapat memahami penyebab dari masalah yang mungkin dihadapai oleh orang lain dan mampu menempatkan diri sesuai dengan harapan orang tersebut. Dengan sifat empati warga sekolah dapat menumbuhkan budaya sekolah yang lebih baik karena dilandasi oleh perasaan yang saling memahami.

9. Pengetahuan dan Kesopanan. Pengetahuan dan kesopanan para personil sekolah yang disertai dengan kemampuan untuk memperoleh kepercayaan dari siapa saja 
akan memberikan kesan yang meyakinkan bagi orang lain. Dimensi ini menuntut para guru, staf dan kepala sekolah tarmpil, profesional dan terlatih dalam memainkan perannya memenuhi tuntutan dan kebutuhan siswa, orang tua dan masyarakat. ${ }^{12}$

Penerapan budaya sekolah termasuk penerapan disiplin semua warga sekolah dapat terwujud apabila semua warga sekolah mempunyai komitmen yang kuat untuk mewujudkannya.

Kepala sekolah selaku pemimpin pembelajaran mempunyai peran yang sangat strategis dalam pencapaian tujuan sekolah. Salah satu faktor yang penting adalah adanya keteladanan (contoh) yang diberikan oleh kepala sekolah. Bapak Pendidikan Nasional Ki Hadjar Dewantara memposisikan guru sebagai pemimin. Jika guru berada di depan, guru harus mampu memberi teladan sikap (sung tulodho). Jika berada di tengah, guru harus mampu teladan kerja (mangun karso). Dan jika berada di belakang, guru harus mampu memberi teladan semangat (tut wuri handayani).

Kepala sekolah selaku pemimpin pembelajaran harus bisa memberikan contoh kepada semua warga sekolah agar tercipta budaya disiplin di sekolah, yang pada akhirnya akan meningkatkan mutu sekolah. Teladan sikap, kerja dan semangat adalah syarat bagi sejawat di lingkungannya untuk ikut disiplin sehingga tujuan penyelenggaraan pendidikan dapat dicapai secara optimal. ${ }^{13}$

\section{METODE PENELITIAN}

\section{Subjek, Lokasi, dan Waktu Penelitian}

Subjek penelitian tindakan di sekolah ini adalah guru-guru SMP Negeri 5 Sengkang Kabupaten Wajo sebanyak 13 orang. Waktu penelitian dilakukan antara bulan Juli sampai dengan September 2011.

\section{Prosedur Penelitian}

Pendekatan yang digunakan dalam penelitian tindakan ini ialah pendekatan kualitatif. Artinya, penelitian ini dilakukan karena ditemukan permasalahan rendahnya tingkat kedisiplinan guru dalam kehadiran di kelas. Permasalahan ini ditindaklanjuti dengan cara menerapkan sebuah model pembinaan kepada guru berupa keteladanan (contoh) yang dilakukan oleh kepala sekolah, kegiatan tersebut diamati kemudian dianalisis dan direfleksi. Hasil revisi kemudian diterapkan kembali pada siklus-siklus berikutnya.

Penelitian ini adalah penelitian tindakan mengadopsi model yang dikemukakan oleh Kemmis dan Taggart seperti dikutip oleh Suranto. ${ }^{13}$ Model ini menggunakan sistem spiral yang dimulai dari rencana, tindakan, pengamatan, refleksi, dan perencanaan kembali yang merupakan dasar untuk suatu rancangan pemecahan masalah. Seperti yang diungkapkan oleh Mills "Stephen Kemmis has created a well known representation of the action research spiral ...". ${ }^{14}$ Peneliti menggunakan model ini karena dianggap praktis dan aktual.

Kegiatan penelitian tindakan sekolah ini, terdiri atas beberapa tahap, yaitu: 1) Perencanaan, 2) Pelaksanaan, 3) Pengamatan, 4) Refleksi. 


\section{Pelaksanaan Tindakan}

Tindakan yang dilakukan dalam penelitian ini adalah pemberian contoh kepada guru mengenai kedisiplinan guru dalam kehadiran di kelas dalam proses pembelajaran oleh kepala sekolah. Diharapkan dengan keteladanan yang diberikan oleh kepala sekolah akan terjadi perubahan atau peningkatan kedisiplinan guru dalam kehadiran di kelas dalam proses pembelajaran.

\section{Teknik Pengumpulan Data}

Teknik pengumpulan data dari penelitian tindakan sekolah ini adalah melalui data kualitatif yang diperoleh dari observasi, pengamatan, maupun wawancara.

\section{Instrumen Penelitian}

Instrumen penelitian yang digunakan dalam penelitian tindakan sekolah ini antara lain adalah: 1) Skala penilaian, 2) Lembar observasi/pengamatan, dan 3) angket.

\section{Teknik Analisis Data}

Analisa data yang digunakan dalam penelitian ini adalah analisa data kualitatif yang bersumber dari data primer maupun empiris. Melalui analisa data ini, dapat diketahui ada tidaknya peningkatan kedisiplinan guru dalam kehadiran di kelas yang merupakan fokus dari penelitian tindakan sekolah ini.

\section{HASIL PENELITIAN DAN PEMBAHASAN}

\section{Deskripsi Profil Lokasi Penelitian}

SMP Negeri 5 Sengkang adalah salah satu SMP Negeri yang berada di sebelah timur wilayah Kecamatan Tempe Kabupaten Wajo, yang berjarak kurang lebih $10 \mathrm{Km}$ dari ibu kota kabupaten dan berada di tengah wilayah Kelurahan Cempalagi dengan Akses jalan masuk yang agak sulit, Lokasi sekolah berada di lokasi terpencil. SMP Negeri 5 sengkang berdiri pada tahun 1984 Sampai saat ini Tenaga Pendidik dan Tenaga Kependidikan berjumlah 22 Orang dan proses pembelajaran berlangsung pada ruangan belajar sebanyak 6 Rombel.

Kondisi wilayah sekitar merupakan daerah pertanian dan industri batu bata atau batu merah, Siswa-siswi SMP Negeri 5 Sengkang berasal dari wilayah sekitar yang meliputi Kelurahan Cempalagi dan Kelurahan Pattirosompe yang berada dekat dengan lingkungan sekolah. Sebagian besar orang tua siswa bekerja sebagai petani, buruh, dan wiraswasta sehingga mempercayakan sekolah tempat belajar dengan sistem pembelajaran CBSA (PAIKEM) - KTSP yang berkarakter dengan harapan supaya anak-anak terkondisi pergaulannya dengan lingkungan sosial yang kondusif (baik).

\section{Deskripsi Hasil Penelitian}

Deskripsi hasil penelitian diuraikan dalam tahapan yang berupa siklus-siklus pembelajaran yang dilakukan. Dalam penelitian ini pembelajaran dilakukan dalam 
dua siklus tujuh pertemuan, setiap siklus tiga kali pertemuan dan satu pertemuan untuk pra-siklus.

Pada pertemuan pertama (pra-siklus) tenaga pendidik dan tenaga kependidikan hadir tepat waktu berhubung karena pada hari itu adalah hari pertama masuk sekolah untuk tahun pelajaran 2011/2012.

\section{Siklus 1}

Siklus 1 terdiri atas beberapa tahap, yaitu: (1) Perencanaan, (2) Pelaksanaan, (3) Pengamatan dan Evaluasi, dan (4) Refleksi.

\section{Perencanaan}

Perencanaan adalah langkah awal yang dilakukan oleh penulis saat akan memulai tindakan. Agar perencanaan mudah dipahami dan dilaksanakan oleh penulis yang akan melakukan tindakan, maka penulis membuat rencana tindakan sebagai berikut:

a) Merumusan masalah yang akan dicari solusinya. Dalam penelitian ini masalah yang akan dicari solusinya adalah masih banyaknya guru yang kurang disiplin dalam kehadiran di kelas pada proses belajar mengajar.

b) Merumusan tujuan penyelesaian masalah/tujuan menghadapi tantangan/tujuan melakukan inovasi/tindakan. Dalam penelitian ini penulis mengambil rencana untuk melakukan tindakan melalui keteladanan kepala sekolah untuk meningkatkan kedisiplinan guru dalam kehadiran mengajar di kelas pada proses belajar mengajar.

c) Merumusan indikator keberhasilan penerapan Keteladanan Kepala Sekolah dalam meningkatkan disiplin guru dalam kehadiran mengajar di kelas pada proses belajar mengajar. Indikator keberhasilan penerapan tindakan ini penulis tetapkan sebesar $75 \%$, artinya tindakan ini dinyatakan berhasil bila $75 \%$ guru tidak terlambat masuk mengajar di kelas dalam proses pembelajaran.

d) Merumuskan langkah-langkah kegiatan penyelesaian masalah/kegiatan menghadapi tantangan/kegiatan melakukan tindakan. Langkah-langkah yang diambil penulis dalam melakukan tindakan antara lain adalah melakukan sosialisasi kepada para guru mengenai penelitian yang akan dilaksanakan, serta menyampaikan tujuan dari penerapan tindakan yang dilakukan oleh penulis. Kepada para guru disampaikan mengenai Keteladanan Kepala Sekolah yang akan diterapkan dalam penelitian ini. Pada siklus pertama ini, akan dipampang/ ditempel diruang guru, maupun diruang TU, peringkat nama-nama guru yang paling rendah tingkat keterlambatan masuk kelasnya sampai yang paling tinggi tingkat keterlambatannya.

e) Mengidentifikasi warga sekolah dan atau pihak-pihak terkait lainnya yang terlibat dalam penyelesaian masalah/menghadapi tantangan/melakukan tindakan. Penulis melakukan identifikasi siapa saja yang dilibatkan dalam penelitian ini. Pihakpihak yang dilibatkan dalam penelitian ini adalah: guru, guru piket, TU, dan siswa. 
f) Mengidentifikasi metode pengumpulan data yang akan digunakan. Metode pengumpulan data yang diambil oleh penulis merupakan data kualitatif melalui observasi, pengamatan serta wawancara kepada siswa mengenai kehadiran guru di kelas pada kegiatan belajar mengajar.

g) Penyusunan instrumen pengamatan dan evaluasi. Dalam pengambilan data, penulis menggunakan instrument berupa lembar observasi/pengamatan, skala penilaian serta angket yang disebarkan kepada guru dan siswa, untuk mengetahui penilaian mengenai tingkat kehadiran guru di kelas dan keteladanan Kepala Sekolah dalam proses kegiatan belajar mengajar.

h) Mengidenifikasi fasilitas yang diperlukan. Fasilitas atau alat bantu yang digunakan dalam penelitian ini antara lain: kertas (lembar pengamatan), alat tulis berupa balpoin, serta jam dinding yang ada disetiap kelas, serta rekap jumlah kehadiran dari setiap guru.

\section{Pelaksanaan Tindakan}

Sesuai dengan rencana, tiga kali pertemuan berturut-turut kepala sekolah hadir 30 menit sebelum jam pelajaran pertama dimulai dan masuk di kelas tepat jam pertama dimulai yaitu: pukul 07.30 WITA dengan membawa perangkat pembelajaran yang lengkap dan meninggalkan kelas tepat pada saat pergantian jam pelajaran berikutnya.

Pelaksanaan penelitian tindakan sekolah selanjutnya dilaksanakan melalui beberapa kegiatan, antara lain:

a) Menyebarkan lembar pengamatan kepada setiap Ketua Kelas atau Sekretaris kelas sebanyak 115 eks., sesuai dengan banyaknya jumlah rombongan belajar di SMP Negeri 5 Sengkang sebanyak 6 rombongan belajar. Dalam lembar pengamatan itu, telah dibuat daftar guru yang mengajar dikelas itu setiap jam dan diberi kolom jam masuk kelas serta jam keluar kelas. Lembar pengamatan dapat dilihat pada lampiran.

b) Berkoordinasi dengan petugas piket yang setiap hari terdiri dari 2 orang petugas, yaitu dari guru yang tidak mempunyai jam mengajar pada hari itu dan satu orang dari tata usaha. Petugas piket akan mengedarkan daftar hadir guru di kelas yang telah dibuat agar dapat melihat tingkat kehadiran guru disetiap kelas dan disetiap pergantian jam pelajaran. Guru yang terlambat lebih dari 15 menit, dianggap tidak hadir dan diberi tanda silang.

c) Setelah selesai jam pelajaran, dilakukan rekapitulasi dari hasil pengamatan, baik dari guru piket, dari siswa maupun dari penulis.

d) Kegiatan tersebut dilakukan terus setiap hari kepada setiap guru selama tujuh minggu (dua siklus).

\section{Pengamatan dan Evaluasi}

Pengamatan atau observasi dilakukan oleh peneliti dengan menggunakan lembar observasi selama satu minggu (satu siklus), untuk semua guru yang berjumlah 13 orang. Selama pengamatan peneliti dibantu atau berkolaborasi dengan guru piket. Pengamatan oleh peneliti meliputi: 
a) Kehadiran guru di kelas

b) Tingkat keterlambatan guru masuk kelas

c) Waktu meninggalkan kelas setelah selesai pelajaran

Dari hasil pengamatan serta rekap dari tingkat kehadiran guru di kelas pada proses belajar mengajar dapat dilihat pada tabel berikut:

\section{REKAPITULASI TINGKAT KETERLAMBATAN GURU PADA KEHADIRAN DI KELAS \\ SIKLUS I}

\begin{tabular}{|c|c|c|}
\hline \multicolumn{3}{|c|}{ Waktu Keterlambatan/Jumlah/Presentase } \\
\hline kurang dari 10 menit & 10 menit s.d 15 menit & lebih dari 15 enit \\
\hline 3 & 3 & 4 \\
\hline $23 \%$ & $23 \%$ & $34 \%$ \\
\hline
\end{tabular}

Dari hasil rekapitulasi tingkat keterlambatan guru di kelas pada proses pembelajaran diperoleh data, sebanyak 3 orang guru terlambat masuk kelas kurang dari 10 menit, 3 orang guru terlambat masuk kelas 10 menit sampai dengan 15 menit, dan 4 orang guru terlambat masuk kelas lebih dari 15 menit, serta 3 orang guru yang hadir tepat waktu mengajar di kelas.

Untuk lebih jelasnya dapat digambarkan pada grafik di bawah ini:

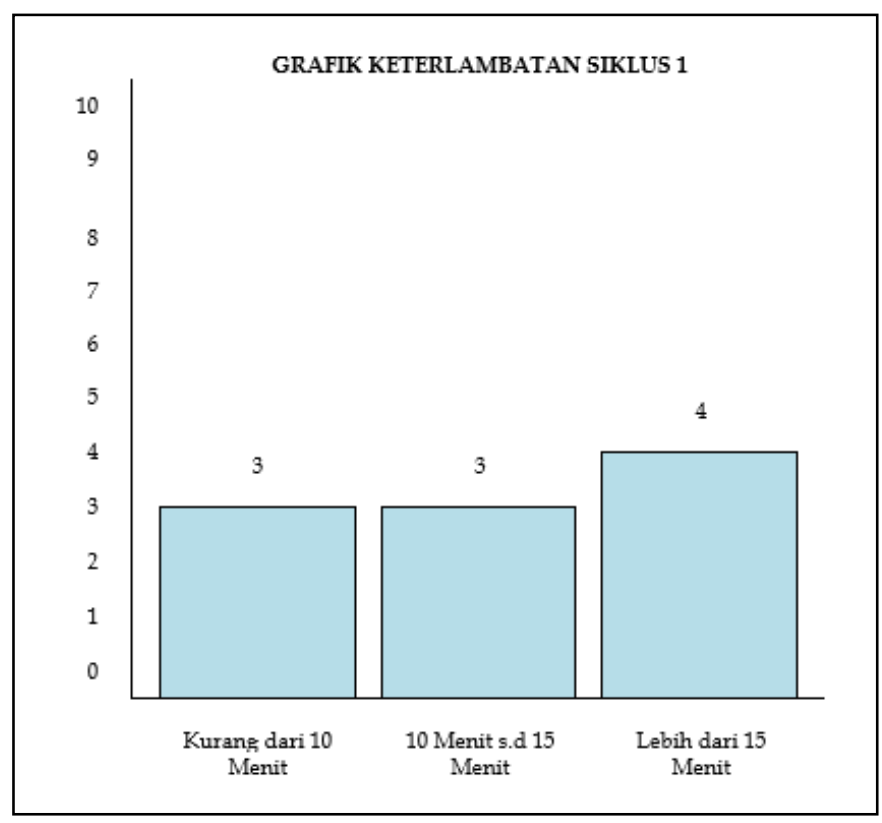

Dari data di atas dapat ditarik kesimpulan bahwa tingkat keterlambatan guru masuk kelas lebih dari 15 menit pada proses kegiatan belajar mengajar masih tinggi yaitu 4 orang atau $34 \%$. Berdasarkan indikator yang telah ditetapkan bahwa keberhasilan tindakan ini adalah $75 \%$, atau bila $75 \%$ guru tidak terlambat lebih dari 10 menit. Pada siklus pertama ini guru yang tidak terlambat lebih dari 10 menit baru 23 $\%$, jadi peneliti berkesimpulan harus diadakan penelitian atau tindakan lagi pada siklus berikutnya atau siklus kedua. 


\section{Refleksi}

Setelah selesai satu siklus maka diadakan refleksi mengenai kelemahan atau kekurangan dari pelaksanaan tindakan pada siklus pertama. Refleksi dilaksanakan bersama-sama kolaborator untuk menentukan tindakan perbaikan pada siklus berikutnya.

\section{Siklus 2}

Siklus 2 terdiri atas beberapa tahap, sama seperti siklus 1 yaitu: 1) Perencanaan, 2) Pelaksanaan, 3) Pengamatan dan Evaluasi, dan 4) Refleksi.

\section{Perencanaan}

Dari hasil refleksi pada siklus pertama, peneliti merencanakan untuk melakukan tindakan sama seperti pada siklus pertama.

Peneliti merencanakan untuk mengumumkan hasil observasi mengenai tingkat keterlambatan guru masuk kelas dalam proses belajar mengajar, pada kegiatan upacara bendera hari Senin. Hal ini terlebih dahulu disosialisasikan kepada semua guru pada saat refleksi siklus pertama.

\section{Pelaksanaan}

Didasarkan pada hasil observasi, hasil pengamatan dan hasil wawancara pada siklus I, tindakan pada siklus II tidak berbeda, hanya beberapa peningkatan kualitas tindakan seperti berikut ini:

a) Setiap hari kepala sekolah hadir 30 menit sebelum jam pertama dimulai dan meninggalkan sekolah setelah jam pelajaran terakhir selesai.

b) Selalu membawa perangkat pembelajaran yang lengkap setiap masuk mengajar di kelas.

c) Setiap hari mengecek kehadiran guru mengajar di kelas melalui jurnal kelas.

d) Mengisi buku agenda Guru.

e) Melaksanakan Supervisi.

\section{Pengamatan dan Evaluasi}

Pengamatan atau observasi dilakukan oleh peneliti dengan menggunakan lembar observasi selama tujuh minggu (dua siklus), untuk semua guru yang berjumlah 13 orang. Selama pengamatan peneliti dibantu atau berkolaborasi dengan guru piket. Pengamatan oleh peneliti meliputi:

a) Kehadiran guru di kelas

b) Tingkat keterlambatan guru masuk kelas

c) Waktu meninggalkan kelas setelah selesai pelajaran

Peneliti juga melakukan penilaian dari hasil lembar observasi yang dibagikan kepada semua siswa untuk mengamati kehadiran guru di kelas. Dari hasil pengamatan serta rekap dari tingkat kehadiran guru di kelas pada proses belajar mengajar pada siklus kedua dapat dilihat pada tabel berikut: 


\section{REKAPITULASI TINGKAT KETERLAMBATAN \\ GURU PADA KEHADIRAN DIKELAS \\ SIKLUS II}

\begin{tabular}{|c|c|c|}
\hline \multicolumn{3}{|c|}{ WAKTU KETERLAMBATAN/JUMLAH/PRESENTASE } \\
\hline kurang dari 10 menit & 10 menit s.d 15 menit & lebih dari 15 menit \\
\hline 10 & 0 & 0 \\
\hline $77 \%$ & $0 \%$ & $0 \%$ \\
\hline
\end{tabular}

Dari hasil rekapitulasi tingkat keterlambatan guru di kelas pada proses pembelajaran diperoleh data, sebanyak 3 orang guru hadir tepat waktu mengajar di kelas, 10 orang guru terlambat masuk kelas kurang dari 10 menit, tidak ada lagi guru yang terlambat baik 10 menit sampai 15 menit maupun lebih dari 15 menit.

Untuk lebih jelasnya, tingkat keterlambatan guru masuk kelas pada proses belajar mengajar pada siklus kedua ini dapat digambarkan pada grafik di bawah ini:

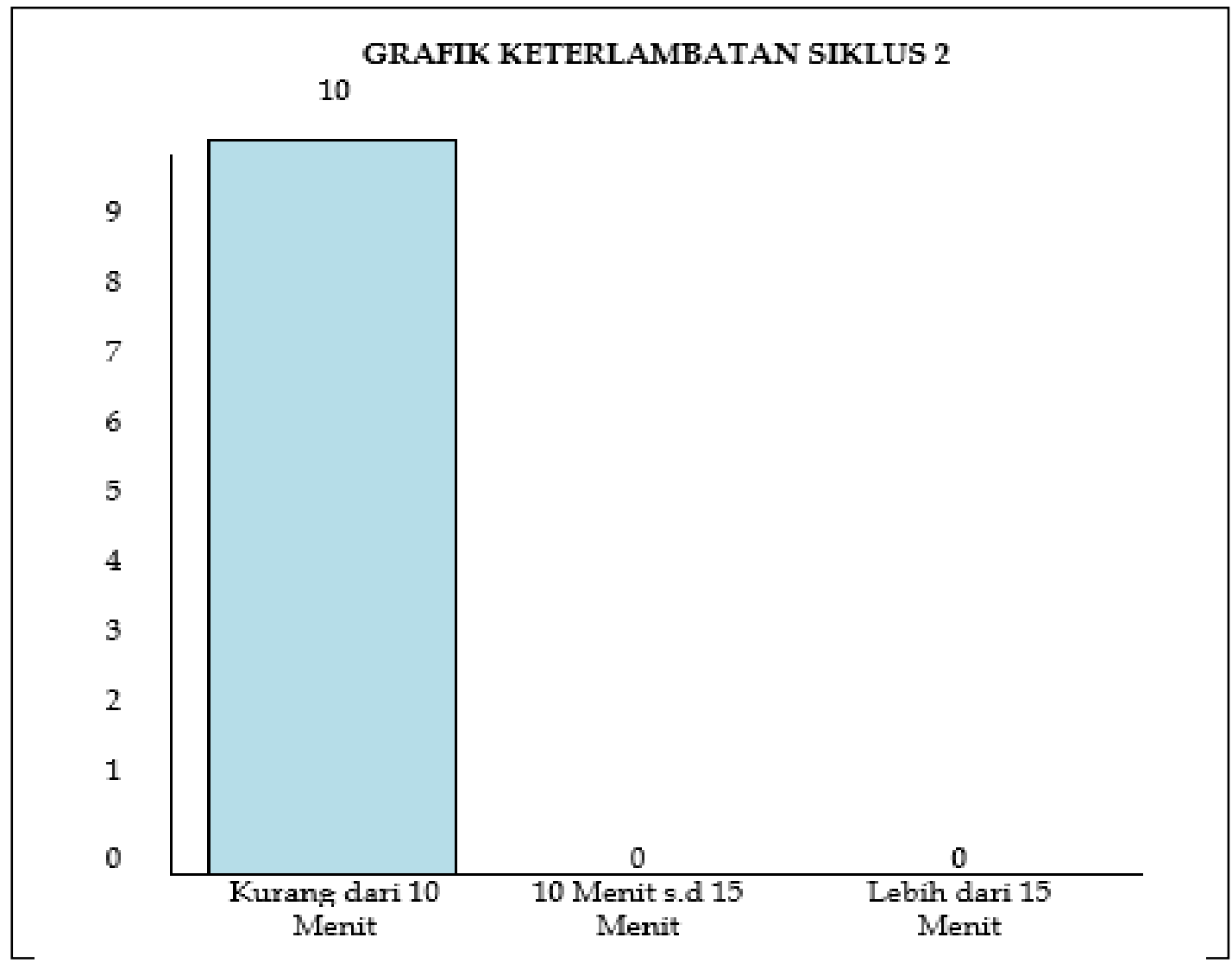

Dari hasil observasi pada siklus pertama dan siklus kedua dapat dilihat ada penurunan tingkat keterlambatan guru di kelas pada kegiatan belajar mengajar, atau terdapat peningkatan kehadiran guru di kelas.

\section{Refleksi}

Setelah selesai pelaksanaan tindakan pada siklus kedua maka diadakan refleksi mengenai kelemahan dari pelaksanaan tindakan pada siklus kedua tersebut. 
Dari hasil observasi dan data yang diperoleh, peneliti mengambil kesimpulan bahwa tindakan yang dilaksanakan pada siklus kedua dinyatakan berhasil, karena terdapat $77 \%$ guru yang terlambat kurang dari 10 menit, dan tidak ada lagi guru yang terlambat baik 10 menit sampai 15 menit maupun lebih dari 15 menit atau melebihi target yang telah ditentukan sebesar $75 \%$.

Hasil Observasi dan pengamatan pada Siklus II menunjukkan bahwa pada tahap ini tidak ada lagi Guru yang terlambat masuk mengajar di kelas lebih dari 15 menit, Guru yang biasanya terlambat masuk mengajar di kelas terutama pada jam pelajaran pertama karena faktor transportasi menemukan solusinya, yaitu ikut pada teman sesama Guru atau Pegawai yang menggunakan transportasi (kendaraan) pribadi. Hal ini dapat kita lihat pada tabel berikut ini:

\section{TANGGAPAN RESPONDEN TENTANG UPAYA MENINGKATKAN DISIPLIN GURU DALAM KEHADIRAN MENGAJAR DI KELAS MELALUI KETELADANAN KEPALA SEKOLAH}

\begin{tabular}{|l|c|c|c|c|c|c|c|}
\hline \multirow{2}{*}{ Kriteria } & \multirow{2}{*}{ Bobot } & F & \multirow{2}{*}{ Nilai } & \multirow{2}{*}{$\%$} & \multicolumn{2}{c|}{ Rata-rata } & Tingkat \\
\cline { 5 - 8 } & & & & & Skor & $\%$ & Partisipasi \\
\hline Selalu & 4 & 9 & 36 & 80 & & & \\
\hline Tidak Selalu & 3 & 2 & 6 & 13 & & & \\
\hline Jarang & 2 & 1 & 2 & 5 & & & \\
\hline Tidak Pernah & 1 & 1 & 1 & 2 & & & \\
\hline \multicolumn{1}{|c|}{ Jumlah } & & 13 & 45 & 100 & 3,46 & & Tinggi \\
\hline
\end{tabular}

Sumber : Olahan Data Primer 2011

\section{Pembahasan}

Dari tabel di atas diperoleh gambaran bahwa keteladanan Kepala Sekolah dapat meningkatkan disiplin Guru dalam kehadiran mengajar di kelas, terutama pada jam pelajaran pertama, hal ini ditandai dengan skor 3,46. Berdasarkan penelitian terhadap responden ternyata terdapat $80 \%$ dari jumlah responden menyatakan bahwa Keteladanan Kepala Sekolah sangat berperanan dalam meningkatkan disiplin Guru terutama dalam kehadiran mengajar di kelas. Sedangkan yang $20 \%$ karena faktor transportasi, yaitu guru yang masih menggunakan transportasi umum, dimana akses jalan masuk ke sekolah memang agak sulit.

\section{SIMPULAN DAN SARAN}

\section{Simpulan}

Berdasarkan hasil penelitian yang telah dilaksanakan dapat disimpulkan bahwa Keteladanan Kepala Sekolah dapat meningkatkan Kedisiplinan Guru dalam kehadiran mengajar di kelas, hal ini terlihat $80 \%$ dari jumlah responden menyatakan bahwa keteladanan Kepala Sekolah sangat berperanan dalam meningkatkan disiplin Guru terutama dalam kehadiran mengajar di kelas. Sedangkan yang 20\% karena 
faktor transportasi, yaitu guru yang masih menggunakan transportasi umum, dimana akses jalan masuk ke sekolah memang agak sulit.

\section{Saran}

Berdasarkan hasil penelitian dan kesimpulan di atas, maka peneliti menyarankan kepada bagian kurikulum untuk menempatkan Guru yang mengajar pada jam pelajaran pertama adalah Guru yang menggunakan alat transportasi (kendaraan) pribadi supaya hadir di sekolah tepat waktu.

\section{CATATAN AKHIR:}

1. Soetjipto, Profesi Keguruan, Jakarta: Proyek Peningkatan Mutu Tenaga Kependidikan, Depdiknas, 1999.

2. Ibid.

3. Ibid.

4. Syamsul Hadi, "Kepemimpinan Pembelajaran", Makalah, disampaikan pada Sosialisasi Akuntabilitas Kinerja Kepala Sekolah dalam Inovasi Pembelajaran, Departemen Pendidikan Nasional, Direktorat Jenderal Peningkatan Mutu Pendidik dan Tenaga Kependidikan, Direktorat Tenaga Kependidikan, 2009.

5. Sudjana, Manajemen Program Pendidikan, Bandung: Falah Production, 2002.

6. Ibid.

7. Akhmad Sudrajat, Manfaat Prinsip dan Asas Pengembangan Budaya Sekolah. [On Line]. Tersedia: http://akhmadsudrajat.wordpress.com/2010/03/04/manfaat-prinsip-dan-asaspengembangan-budaya-sekolah/ [06 Oktober 2010]

8. Soetjipto, op.cit.

9. Akhmad Sudrajat, op.cit.

10. Ibid.

11. Ibid.

12. Ibid.

13. Studi yang dilakukan Zimmerman menunjukkan bahwa melihat contoh yang baik efektif meningkatkan ketangguhan diri (self efficacy) orang lain untuk berperilaku sama atau lebih baik. Lihat, Zimmerman, "Self Efficacy and Educational Development" dalam Bandura, Self Efficacy in Changing Societies, New York: Cambridge University Press, 1995. h. 202-204.

13. Suharsimi Arikunto, Prosedur Penelitian: Suatu Pendekatan Praktek, Jakarta: Rineka Cipta, 2002.

14. Ibid.

\section{DAFTAR PUSTAKA}

Sudrajat, Akhmad. Manfaat Prinsip dan Asas Pengembangan Budaya Sekolah. [On Line]. Tersedia: http://akhmadsudrajat.wordpress.com/2010/03/04/manfaat-prinsip-dan-asaspengembangan-budaya-sekolah/ [06 Oktober 2010]

Arikunto, S. Prosedur Penelitian Suatu Pendekatan Praktek. Jakarta: Rineka Cipta, 2002.

Aunurrahman. Belajar dan Pembelajaran. Bandung: Alfabeta, 2009.

Barry J. Zimmerman. "Self Efficacy and Educational Development" dalam Bandura, Self Efficacy in Changing Societies, New York: Cambridge University Press, 1995 
Boediono, Koster, Wayan. Teori dan Aplikasi Statistik dan Probabilitas. Bandung: PT Remaja Rosdakarya, 2001.

Departemen Pendidikan Nasional. Undang-undang Nomor 20 Tahun 2003 Tentang Sistem Pendidikan Nasional. Jakarta: Depdiknas, 2003.

Departemen Pendidikan dan Kebudayaan Republik Indonesia. Kamus Besar Bahasa Indonesia. Jakarta: Balai Pustaka, 1988.

Ancok, Djamaluddin, Teknik Penyusunan Skala Pengukuran, PPKM UGM, Yogyakarta, 1989.

Sanjaya, W., Kurikulum dan Pembelajaran: Teori dan Praktik Pengembangan Kurikulum Tingkat Satuan Pendidikan (KTSP), Jakarta: Kencana Prenada Media Group, 2008.

Sudjana, Manajemen Program Pendidikan, Bandung: Falah Production, 2002.

Sugiyono, Metode Penelitian Administrasi, Bandung: Alfabeta, 2005.

Soetjipto, Profesi Keguruan, Jakarta: Projek Peningkatan Mutu Tenaga Kependidikan, Depdiknas, 1999.

Hadi, Syamsul, Kepemimpinan Pembelajaran, Makalah Disampaikan pada Sosialisasi Akuntabilitas Kinerja Kepala Sekolah dalam Inovasi Pembelajaran, Departemen Pendidikan Nasional, Direktorat Jenderal Peningkatan Mutu Pendidik dan Tenaga Kependidikan, Direktorat Tenaga Kependidikan, 2009. 